\title{
Nutrition of Floricultural Crops: How Far Have We Come?
}

\author{
Ellen T. Paparozzi ${ }^{1}$ \\ Department of Agronomy and Horticulture, University of Nebraska, Lincoln, NE 68583-0724
}

According to Seeley (1979), even though the Society for Horticultural Science was formed in 1903, it wasn't until the 1930s that research papers on the subject of floriculture were published in our journal. There were, however, numerous college and university bulletins about floricultural crops which included fertilizer studies (for example, Blake, 1915).

Despite the sluggish start, in the last 25 years, in the American Society of Horticultural Science's three journals (Journal of the American Society for Horticultural Science, HortScience, and HortTechnology) alone, there have been over 240 publications relating to nutrition of floricultural crops. Journals such as Scientia Horticulturae, Journal of Plant Nutrition, Agrochemica, Journal of Environmental Horticulture as well as others also publish papers on this topic. Thus, the focus of this article will be on research published in ASHS journals. Even with this narrowed focus, only a sampling of the research that has occurred can be mentioned here.

Floriculture in its broadest sense involves growth and development physiology, culture, management and postharvest physiology of cut flowers, potted flowering and foliage plants, cacti and carnivorous plants, bedding plants and herbaceous perennials including forbs and geophytes. Adequate elemental content of these plants is critical at all growth stages to ensure a marketable product. For a more complete picture of the art and science of floriculture see the "History of U. S. Floriculture: the People, Events and Technology that shaped the Past 100 Years" (Greenhouse Grower, 1999). An additional historical-based article about USDA research including floriculture crops from 1862 to 1940 is by Griesbach and Berberich (1995).

To begin an article like this, one should discuss essential elements and how essentiality is determined. With addition of nickel, there are now 17 elements (carbon, hydrogen, oxygen, nitrogen, phosphorous, sulfur, potassium, magnesium, calcium, iron, manganese, boron, copper, zinc, molybdenum, chlorine) required for a plant to complete its life cycle-one of the criteria for determining if an element is essential. In 1983, Joiner, Poole, and Conover published an in depth review article titled "Nutrition and Fertilization of Ornamental Greenhouse Crops" which covers a discussion of the essential elements and brings together much of the floriculture literature as it broaches the topics of factors affecting the frequency and quantity of fertilizer application and nutrient/fertilizer requirements for the then major crops.

The first paper in an ASHS publication (Proceedings of the American Society for Horticultural Science) specifically dealing with nutrition of floriculture crops was titled "A Method for Studying Nutrient Deficiencies in Greenhouse Crops (Laurie and Mc Elwee, 1934). This paper describes a continuous drip system used to apply four different nutrient solutions (complete, N, P, K) to a number of different floricultural crops. The plants were grown in acid-washed sand. The solutions were prepared from reagent grade chemicals that included the six macroelements plus $\mathrm{Fe}, \mathrm{Mn}, \mathrm{Na}$, and $\mathrm{Cl}$. Visual observations of deficiency were recorded. Sound familiar? Since then researchers have basically expanded on this theme using or creating new technology to help identify and quantify nutrient deficiencies, sufficiencies and toxicities in floricultural crops. Each paper presents a different twist on classic nutrient studies all ultimately aimed at understanding how nutrients interact during the plant's life cycle.

\section{MEDIA AND MIXES}

Since the development of the University of California system mixes (Baker, 1957) and the Cornell peat-lite mixes (Boodley and Sheldrake, 1967), more and more floriculturists have been and still are experimenting with nonsoil containing mixes and additives (for example, hydrophilic polymers, Blodgett, et al., 1993). This is in comparison to ornamentals

${ }^{1}$ This article is submitted as Nebraska Agricultural Research Division journal series number 13996 . such as trees and shrubs, which are still mainly field grown. That is not to say that floriculture researchers don't work in the field and in soil (herbaceous perennials - Duarte and Perry, 1988), it's just that the main emphases have been on alternative mixes in greenhouse or controlled environments. Research on media has ranged from hydroponics to peat-based mixes to bark-based mixes (Albrecht et al.,1980), to sewage sludge/biosolids-based (Chaney et al., 1980; Williams and Nelson, 1992b) or recycled tire-based mixes (Newman et al., 1997) to zeolites (Carlino et al., 1998) to plant by-products such as coir (Meerow, 1994; Wang and Blessington, 1990) as sole or component part(s) of media (Fonteno and Nelson, 1990; Conover and Poole, 1983). Key variables such as physical characteristics, salinity, nutrient and water retention interactions have been the objectives of this research as all of these variables affect nutrient availability to plants (Rupp and Dudley, 1989). The importance of nutrient element interactions with irrigation sources and $\mathrm{pH}$ also received attention for many types of mixes (Yelanich and Biernbaum, 1993; Argo and Biernbaum, 1996; Argo and Biernbaum, 1997). Commercial products with and without a nutrient charge have followed suit producing a wide variety of quality, ready-to-use bagged mixes. The end result of commercial use for these different types of mixes is still being governed by grower preference, availability and cost as much as nutrient- and water-retaining capacity and efficacy.

With the great increase in use of nonsoil-based media a different method of mix analysis was needed. The Spurway analysis method used for soils wasn't adequate for these lightweight, organic intensive blends (Westerman, 1990; Markus, 1986). Alternatives to standard soil elemental and $\mathrm{pH}-\mathrm{EC}$ analysis such as the saturated media extract (SME) (Warncke, 1986) and the pour-through method were developed and compared for different types of mixes (Wright, 1986; Yeager, et al., 1983). Currently, the rhizon soil solution sampler (RSSS) holds promise as a quick, inexpensive, nondestructive method that does not overly disturb pot media for determining $\mathrm{pH}, \mathrm{EC}, \mathrm{NO}_{3}-\mathrm{N}$ and $\mathrm{K}$ (Argo et al.,1997). Research on the press-extraction method, specifically developed for plug mix analysis, demonstrated strong correlations for nutrient content, $\mathrm{pH}$ and $\mathrm{EC}$ with the SME and thus, also shows promise for practical use (Scoggins et al., 2001).

\section{FERTILIZER FORMULATIONS AND DELIVERY SYSTEMS}

Research in this area has covered soluble, slowly soluble, and controlled release/encapsulated formulations (Kovacic and Holcomb, 1980) as well as specific elemental source (N. Conover and Poole, 1986; Schrock and Goldsbery, 1982; Woodson and Boodley, 1982a). Many studies have been designed to test the interaction of fertilizer formulation, media type and/or plant cultivar both during specific growth phases and postproduction (Tayama and Carver, 1992; Vetanovetz and Petersen, 1990; Haver and Schuch, 1996; Nell et al, 1997; Starkey and Pederson, 1997).

Nutrients must be diluted to reach the roots or leaves of plants. Thus, the confounding of water and fertilizers (fertigation) and the need to investigate different methods of nutrient solution delivery as well as water quality, alkalinity and $\mathrm{pH}$ (Reed, 1996). Research has been done using almost every fertilizer delivery system available from hydroponics (Jensen, 1997; Hickleton et al., 1987) and recirculating nutrient solutions (Woodson and Boodley, 1982b) to sand culture; ebb and flood benches, drip irrigation to sub-irrigation (Kent and Reed, 1996; Todd and Reed, 1998), nutrient film technique (NFT) (Graves, 1983) to foliar sprays of specific elements (Harbaugh and Woltz, 1989; McAvoy and Bible, 1996; Gilliam and Zlesak, 2000). The objectives of these studies are ecologically sound and include minimizing or eliminating runoff, fertilizer applications, leachate (Cox, 1993; Ku and Hershey, 1997; Lang and Pannuk, 1998) and water application as well as recycling of fertilizer or waste water (Sanderson, et al., 1985). Even studies using saline and recycled irrigation water (Koch and Holcomb, 1983; Biernbaum, 1992) have been conducted with an eye 
to the future scarcity and demand for potable water. The mobility of individual elements in a mix is also important and impacts delivery system and formulation (P, Yeager and Barrett, 1984; micronutrients, Broschat and Donselman, 1985). Implementing these studies at the commercial level is much harder as many of these more efficient systems are costly when installed new and even more costly when retrofitted to existing greenhouses. Also, some systems will be better suited for certain greenhouse range sizes and certain crops such as potted plants (Uva, et al., 2001). Still, floriculture researchers have heightened awareness and provided technology transfer to the industry.

\section{NUTRIENT ANALYSIS AND PLANT CONTENT}

Understanding the role of nutrients as a driving force for physiological reactions including environmental, stress and postharvest physiology has been broached by numerous researchers and a body of knowledge is beginning to accumulate that will help both scientists and growers come to a better understanding of this complex interaction (Borch et al., 1998; Hansen and Lynch, 1998; Jeong and Lee, 1992; Mankin and Flynn, 1996; Nell et al., 1989; Neumaier et al., 1987; Salac and Fitzgerald, 1983; van Iersel et al., 1998; Wang and Sauls, 1988; Whipker and Hammer, 1997; White and Biernbaum, 1984; Woodson et al., 1984).

Researchers have continued pursuing determinations of deficient/ critical (Ca, Hershey and Merritt, 1987; Woltz and Harbaugh, 1986 and Ku and Hershey, 1991; K, Hershey and Paul, 1981; S, Dale et al. 1990), sufficient and toxic concentrations (B, Brown et al., 1999; Fe, Albano et al., 1996; Mo, Hammer and Bailey, 1987; micronutrients, Lee et al., 1996) for many nutrients using leaves of floricultural plants (geranium, Widmer et al., 1986; hydrangea, Bailey and Hammer, 1988; anthurium, Higaki et al., 1992). Unfortunately, sometimes plant response to nutrient concentration is cultivar specific (Mo and poinsettia, Cox, 1992; Mn and N, Reddy and Mills, 1991), thus, making generalizations more difficult. Additionally, research has been necessary for certain crops that require specific, nonessential elements, e.g., aluminum for blue hydrangea flowers (Blom and Piott, 1992) to ensure a marketable crop.

Work continues on estimating the efficiency of plant usage of single elements (Rose et al., 1994) and balances or ratios of elements such as NH4:NO3 (Roude et al., 1991; Cox and Seeley, 1984) Ca and N (Lawton et al.,1989; Smith, et al, 1998), N and S (Huang et al., 1997). However, only recently has root nutrient concentration been studied (Albano and Miller, 2001; Picchioni et al., 2001). Methods for quick determination of elements such as Cardy meters for nitrate and potassium have been used, but produce variable results (Rosen, et al., 1996). Nondestructive methods for determining nutrients are under investigation, e.g., $\mathrm{N}$ determination using a chlorophyll meter (Jones, 1998).However, for reliable leaf nutrient analysis a sample still must be taken, digested and analyzed by specific lab procedures.

To date, floriculture has no parallel to DRIS (diagnosis and recommendations integrated systems), which are standard norms available for diagnosing deficiency, sufficiency and toxicity in fruit and some vegetable crops (Parent and Granger, 1989). Floriculture generally tends to use the critical value approach (CVA) to determine the cause of deficiency or toxicity problems. Numerous books/manuals plus a CD-rom (American Phytopathological Society, 2000) have been developed to bring together tissue standards and pictures identifying nutrient problems for a wide range of crops including floricultural crops (Windsor and Adams, 1987; Reuter and Robinson, 1997; Mills and Jones, 1996). Books devoted to specific floriculture crops such as poinsettias or roses are also available. These indicate how much (fertilizer rate) of which element a particular plant needs as well as the specific elemental concentration in leaves (Ecke, et al., 1990; Langhans, 1987; Armitage, 1993; Nau, 1996; Holcomb, 1994; Rogers and Tija, 1990; Holley and Baker, 1991; De Hertogh and Le Nard, 1993). These books have the advantage of discussing plant nutrition as a part of the production scheme rather than just a table of values.

Trade magazines such as Greenhouse Grower and GrowerTalks feature new crops with growing schedules that include recommended fertilizer rates. A current text for teaching floriculture crop production and physiology which helps students learn about the role of fertilizers in floriculture crop production is Dole and Wilkins, 1999.

\section{GOING ORGANIC}

While parts of most floricultural crops would not be deemed edible (Kelly et al., 2002) and therefore, not a concern for pesticide or fertilizer residue, there is a definite gardening trend of using natural sources of fertilizers such as composts and manures. Such usage was a more common practice 70 or more years ago as noted in Pridham and Thompson (1930) where manure was the preplant fertilizer used for their study on gladiolus. Until recently (Choi and Nelson, 1996; Fitzpatrick et al., 1998; Wilson et al., 2001; Young et al., 2002), floriculturists have left this source of plant nutrients for studies by others. However, it would be easy to incorporate this source of fertilizer into floriculture research as farmers and researchers interested in organic vegetable production have done quite extensive research (Hartz et al., 2000; Korcak, 1992).

\section{THE FUTURE}

As predicted by Seeley (1979), sales of cut flowers, bedding plants and potted plants have increased over the last 25 years. Additionally, herbaceous perennials have burst onto the marketing scene. Crops once thought to be minor, such as potted orchids (Britt, 2000), enjoy more sales than those solely attributable to the hobbyist. Tropical cut flowers and foliage are common components of floral designs and the theme for the 21st Century from gardens to wedding bouquets is variety and lots of it! Variety in color, variegation, plant type and habit. The problem for scientists studying plant nutrition is that not all species respond similarly to the same rates of essential and nonessential elements. Thus, the need for trials for each species or even variety. This is juxtaposed with the increased costs of research, reduced government funding and grant opportunities. Additionally, it seems that we are returning to the beginning of the last century in terms of having fewer scientists dedicated solely to plant nutrition who are involved in teaching, research and extension at land-grant universities and colleges.

Thus, research in plant nutrition has a dicey future at best. The rising costs of graduate student stipends ( $\$ 20,000$ to $\$ 30,000$ per year) and the lack of sources willing to commit $\$ 100,000$ or more to a 3-year project in plant nutrition make justifying this research difficult. Continuing decreases in federal and state funding leave newer horticulture faculty without technical support. Again, they may become like their predecessors of the 1930s and end up doing most of the physical work themselves. Forming teams to investigate interactions of plant nutrition with insects, diseases and other physiological phenomena may be a solution. Recently, research on the nutrient content of leaves and the interaction with pests (Bagatto et al., 1991; Harbaugh et al., 1983) and diseases (Chase and Poole, 1984) has enjoyed renewed attention and federal funding. For biochemically inclined horticulturists, there are single element pathways that still are incomplete (example S) and interactions with other biochemical and physiological processes (for example secondary compounds) yet to explore. For those genetically inclined the role of nutrients and genetics is very promising and the role of nutrients in signal transduction leaps to mind. Additionally, molecular biologists and plant taxonomists are reclassifying and realigning many plant families and genera. Perhaps more broadly based nutrient requirements or generalizations can be made if we look at floricultural crops more as a group, for example, perennial herbs (geranium) and woody angiosperms (poinsettia and chrysanthemum). Critical choices of crops and mathematical models to extend to crops not tested need to be developed (Dole and Wilkins, 1991; Milks et al., 1989; Parent and Dafir, 1992; Willits et al, 1992). Floriculturists interested in plant nutrition for diagnosing problems may want to revisit the CVA system as the method of choice (Parent and Dafir, 1992).

Technology transfer from university to industry will remain important even though publishing in trade magazines may be viewed as less valuable than journal articles. So, in terms of the plant nutrition researcher directly serving the floricultural industry, there may be an expanding role for individuals with a good background in plant nutrition to serve as the horticultural equivalent of the agronomic crop consultant. These individuals would not only solve grower-related problems, but also could serve as the link between industry and university researchers in terms of identifying needed research and funding. ASHS provides a 
mechanism for certification of advisors through the $\mathrm{CPH}$ program.

In addition to the challenges of funding, keeping up with the on-going scientific changes will be a struggle. Reviewing the past literature is also a daunting task and one often minimized by graduate students as pivotal articles from the 1950s and 1960s are not included in library computer databases. Researchers need to be careful about key words (additional index words) inclusions on journal articles as that may make the difference whether their paper becomes a reference.

While we, as scientists, have made good progress in reporting repeatable experiments, it is only since 1998 that all floriculture nutrition and related articles have included well-described experimental designs and data analysis methods. This trend should continue in two ways. First, the use of smarter designs should be promoted. For example, incomplete block and response surface designs (Clemens and Morton, 1999) can reduce costs and allow screening of large numbers of treatment factors (including varieties) and complex interactions. Second, data analysis should move beyond linearity and simple mean comparisons. For example, many nutrient response relationships are nonlinear; use of nonlinear methods results in better insight and more efficient use of the data.

Lastly, we will need to revisit and redefine all of plant nutrition in terms of its role in environmental pollution. Fertigating greenhouse floors via heavy leaching losses (McAvoy, 1994) is no longer acceptable (Latimer et al., 1996) and many of our international colleagues are well ahead of us (Papadoupolous, 1999). We need to reduce and balance fertilizer inputs despite the current minimal cost (Kuehny and McMahon, 1998; Williams and Nelson, 1992a). We need to develop ways to reuse/recycle/reclaim spent mixes rather than tossing them in landfills.

During the 21 st century, research challenges - basic and applied as well as those in between - will still present themselves. There will just be fewer floriculturists/horticulturists to solve them.

\section{Literature cited}

Albano, J.P. and W.B. Miller. 2001. Photo-degradation of FeDTPA in nutrient solutions II. Effects on root physiology and foliar Fe and Mn levels in marigold. HortScience 36:317-320.

Albano, J.P., W.B. Miller and M.C. Halbrooks. 1996. Iron toxicity stress causes bronze speckle, a specific physiological disorder of marigold (Tagetes erecta L.). J. Amer. Soc. Hort. Sci. 121:430-437.

Albrecht, M.L., M.E. Watson, and H.K. Tayama. 1980. Chemical characteristics of composted hardwood bark as they relate to plant nutrition. J. Amer. Soc. Hort. Sci. 107:1081-1084.

American Phytopathological Society. 2000. Nutrient deficiencies and toxicities of plants. APS Digital Collections, APS Press, Amer. Pathol. Soc., St. Paul, Minn.

Argo, W.R. and J.A. Biernbaum. 1996. The effect of lime, irrigation-water source and water soluble fertilizer on root-zone $\mathrm{pH}$, electrical conductivity and macronutrient management of container root media with impatiens. J. Amer. Soc. Hort. Sci. 121: 442-452.

Argo, W.R. and J.A. Biernbaum. 1997. The effect of root media on root-zone $\mathrm{pH}$, calcium and magnesium management in containers with Impatiens. J. Amer. Soc. Hort. Sci. 122:275-284.

Argo, W.R., B.J. Weesies, E.M. Bergman, M. Marshal, and J.A. Biernbaum. 1997. Evaluating rhizon soil solution samplers as a method for extracting nutrient solution and analyzing media for container grown crops. HortTechnolgy 7:404-408.

Armitage,A.M. 1993. Specialty cut flowers. Varsity Press/Timber Press,Portland, Ore.

Bagatto, G., T.J. Zmijowskyj, and J.D. Shorthouse. 1991. Galls induced by Diplolepis spinosa influence distribution of mineral nutrients in the shrub rose. HortScience 26:1283-1284.

Bailey, D.A. and P.A. Hammer. 1988. Evaluation of nutrient deficiency and micronutrient toxicity symptoms in florists' hydrangea. J. Amer. Soc. Hort. Sci. 113:363-367.

Baker, K. (ed.). 1957. The U.C. System for producing healthy container-grown plants. Univ. Cal. Agr. Ext. Serv. Man. 23.

Biernbaum, J.A. 1992. Root-zone management of greenhouse container-grown crops to control water and fertilizer use. HortTechnolgy 2:127-132.

Blake, M.A. 1915. Humidity, soil, fertility studies with roses. N.J. Agr. Expt. Sta. Bul. 277

Blodgett, A.M., D.J. Beattie, J.W. White ,and G.C. Elliott. 1993. Hydrophilic polymers and wetting agents affect absorption and evaporative water loss. HortScience 28:633-635.
Blom, T.J. and B.D. Piott. 1992. Florists' hydrangea blueing with aluminum sulfate applications during forcing. HortScience 27:1084-1087.

Boodley, J.W. and R. Sheldrake. 1967. Commercial peat-lite media for commercial plant growing. Cornell Univ. Ext. Info. Bul. 43.

Borch, K., K.M. Brown, and J.P. Lynch. 1998. Improving bedding plant quality and stress resistance with low phosphorus. HortTechnolgy 8:575-578.

Britt, J. 2000. The status of the commercial production of potted orchid around the world. HortTechnolgy 10:435-436.

Broschat, T.K. and H.M. Donselman. 1985. Extractable Mg, Fe, Mn, Zn, and Cu from a peat-based container medium amended with various micronutrient fertilizers. J. Amer. Soc. Hort. Sci.110:196-200.

Brown, P.H., H. Hu, and W.G. Roberts. 1999. Occurrence of sugar alcohols determines boron toxicity symptoms of ornamental species. J. Amer. Soc. Hort. Sci. 124:347-352.

Carlino, J.L., K.A. Williams, and E.R. Allen. 1998. Evaluation of zeolitebased root media for potted chrysanthemum production. HortTechnology 8:373-378.

Chaney, R. L., J.B. Munns, and H.M. Cathey. 1980. Effectiveness of digested sewage sludge compost in supplying nutrients for soilless potting media. J. Amer. Soc. Hort. Sci.105:485-492.

Chase, A.R. and R.T. Poole. 1984. Investigation into the roles of fertilizer, level and irrigation frequency on growth, quality and severity of pythium root rot of Peperomia obtusifolia. J. Amer. Soc. Hort. Sci. 109: 619-622.

Choi, J.M. and P.V. Nelson. 1996. Developing a slow-release nitrogen fertilizer from organic sources: III. Isolation and action of a feather-degrading actinomycete. J. Amer. Soc. Hort. Sci. 121:639-643.

Clemens, J. and R.H. Morton. 1999. Optimizing mineral nutrition for flower production in Heliconia 'Golden Torch' using response surface methodolgy. J. Amer. Soc. Hort. Sci 124:713-724.

Conover, C.A. and R.T. Poole. 1983. Sedge moss peat, solite and Melaleuca quinquenervia as potting medium components for shadehouse production of foliage plants. HortScience 18: 888-890.

Conover, C.A. and R.T. Poole. 1986. Nitrogen source effects on growth and tissue content of selected foliage plants. HortScience 21:1008-1009.

Cox, D.A. 1992. Poinsettia cultivars differ in their response to molybdenum deficiency. HortScience. 27:892-893.

Cox,D.A. 1993. Reducing nitrogen leaching losses from containerized plants: the effectiveness of controlled release fertilizers. J. Plant Nutr. 16:533-545.

Cox, D.A. and J.G. Seeley. 1984. Ammonium injury to poinsettia: Effects of $\mathrm{NH}_{4}-\mathrm{NO}_{3}-\mathrm{N}$ ratio and $\mathrm{pH}$ control in solution culture on growth, $\mathrm{N}$ absorption and N utilization. J. Amer. Soc. Hort. Sci. 109:57-61.

Dale, M.E., E.T. Paparozzi and J.D. Carr. 1990. Sulfur deficiencies in poinsettia. HortScience 25:424-426.

DeHertogh, A. and M. LeNard (eds.). 1993. The physiology of flower bulbs. Elsevier. Amsterdam, The Netherlands.

Dole, J.M. and H.F. Wilkins. 1991. Relationship between nodal position and plant age on the nutrient composition of poinsettia leaves. J. Amer. Soc. Hort. Sci. 116:248-252.

Dole, J.M. and H.F. Wilkins. 1999. Floriculture: Principles and species. Prentice-Hall, Upper Saddle River, N.J.

Duarte, M. and L.P. Perry. 1988. Field fertilization of Heuchera sanguinea 'Splendens'. HortScience 23:1084.

Ecke, Jr., P. O. A. Matkin, and D.E. Hartley. 1990. The poinsettia manual. 3rd ed. Paul Ecke Poinsettias, Encinitas, Calif.

Fitzpatrick, G.E., E.R. Duke, and K.A. Klock-Moore. 1998. Use of compost products for ornamental crop production: Research and grower experience. HortScience 33:941-944.

Fonteno, W.C. and P.V. Nelson. 1990. Physical properties of and plant responses to rock-wool amended media. J. Amer. Soc. Hort. Sci. 115:375-381.

Gillman, J.H. and D.C. Zlesak. 2000. Mist applications of sodium silicate to rose (Rosa L. x 'Nearly Wild') cuttings decrease leaflet drop and increase rooting. HortScience 35:773.

Graves, C. J. 1983 The nutrient film technique. Hort. Rev. 5:1-44.

Greenhouse Grower. 1999. History of U.S. Floriculture. Greenhouse Grower Mag. Commemorative ed. Fall.

Griesbach, R.J. and S.M. Berberich. 1995. The early history of research on ornamental plants at the U.S. Department of Agriculture from 1862 to 1940. HortScience 30:421-425.

Hammer, P.A. and D.A. Bailey. 1987. Poinsettia tolerance of molybdenum. HortScience 22:1284-1285.

Hansen, C.W. and J. Lynch. 1998. Response to phosphorus availability during vegetative and reproductive growth of chrysanthemum: II. Biomass and phosphorus dynamics. J. Amer. Soc. Hort Sci 123:223-229.

Harbaugh, B.K., J.F. Price and C.D. Stanley. 1983. Influence of leaf nitrogen and leaf miner damage and yield of spray chrysanthemum. HortScience $18: 880-881$

Harbaugh, B.K. and S.S. Woltz. 1989. Fertilization practice and foliar-bract calcium sprays reduce incidence of marginal bract necrosis of poinsettia. 
HortScience 24:465-468.

Hartz, T.K., J.P. Mitchell, and C. Giannini. 2000. Nitrogen and carbon mineralization dynamics of manures and composts. HortScience 35:209-212.

Haver, D.L. and V.K. Schuch. 1996. Production and postproduction performance of two new guinea Impatiens cultivars grown with controlled-release fertilizer and no leaching. J. Amer. Soc. Hort. Sci. 121:820-825.

Hershey, D.R. and J.L. Paul. 1981. Critical foliar levels of potassium in pot chrysanthemum. HortScience 16:220-222.

Hershey, D.R. and R.H. Merritt. 1987. Calcium deficiency symptoms of heartleaf philodendron. HortScience 22:311.

Hickleton, P.R., C.R. Blatt, and R.J. O'Regan. 1987. Hydroponic production of cut chrysanthemums: A commercial trial. HortScience 22:287-289.

Higaki, T., J.S. Imamura, and R.E. Paul. 1992. N, P, and K rates and leaf tissue standards for optimum Anthurium andraeanum flower production. HortScience 27:909-912.

Holcomb, J.E. 1994. Bedding plants IV. Ball Publ., Batavia, Ill.

Holley, W.D. and R. Baker. 1991. Carnation production II. Kendall/Hunt Publishing Co., Dubuque, Iowa.

Huang, L.C., E.T. Paparozzi, and C. Gotway. 1997. The effect of altering nitrogen and sulfur supply on the growth of cut chrysanthemums. J. Amer. Soc. Hort. Sci. 122:559-564.

Jensen, M.H. 1997. Hydroponics. HortScience 32:1018-1021.

Jeong, B.R. and C.W. Lee. 1992. Growth suppression and raised tissue C contents in $\mathrm{NH}_{4}^{+}$-fed marigold, petunia and salvia. J. Amer. Soc. Hort. Sci. 117:762-768.

Joiner, J.N., R.T. Poole, and C.A. Conover. 1983. Nutrition and fertilization of ornamental greenhouse crops. Hort. Rev. 5:317-403.

Jones, Jr., J.B. 1998. Plant nutrition manual. CRC Press, Boca Raton, Fla.

Kelly, K.M., B.K. Behe, J.A. Biernbaum, and K.L. Poff. 2002. Consumer purchase and use of edible flowers: Results of three studies. HortTechnology $12: 282-287$.

Kent, M.W. and D.W. Reed. 1996. Nitrogen nutrition of new guinea impatiens 'Barbados' and Spathiphyllum 'Petite' in a subirrigation system. J. Amer. Soc. Hort. Sci. 121:816-819.

Koch, G.M. and E.J. Holcomb. 1983. Utilization of recycled irrigation water on marigolds fertilized with osmocote and constant liquid fertilization. J. Amer. Soc. Hort. Sci. 108: 815-819.

Korcak, R.F. 1992. Early roots of the organic movement: A plant nutrition perspective. HortTechnolgy 2:263-267.

Kovacic, M.T. and E.J. Holcomb. 1980. Effects of controlled-release fertilizers and application methods on growth and leaf elemental concentration in Kalanchoe blossfeldiana 'Pixie'. J. Amer. Soc. Hort. Sci. 106:549-552.

Ku, C.S.M. and D.R. Hershey. 1991. Calcium deficiency symptoms of Epipremnum aureum. HortScience 26:606.

Ku, C.S.M. and D.R. Hershey. 1997. Growth response, nutrient leaching and mass balance for potted poinsettia. II. Phosphorus. J. Amer. Soc. Hort. Sci. 122:459-464.

Kuehny, J.S. and M.J. McMahon.1998. Hothouse bothers: A case study. HortTechnology 8:606-609.

Lang, H.J. and T.R. Pannkuk. 1998. Effects of fertilizer concentration and minimum-leach drip irrigation on the growth of new guinea impatiens. HortScience 33:683-688.

Langhans, R.W. (ed.). 1987. Roses: A manual of greenhouse rose production. Roses Inc., Haslett, Mich.

Latimer, J.G., R.D. Oetting, P.A. Thomas, D.L. Olson, J.R. Allison, S.K. Braman, J.M. Ruter, R.B. Beverly, W. Florkowski, C.D. Robaker, J.T. Walker, M.P. Garber, O.M. Lindstrom, and W.G. Hudson. 1996. Reducing the pollution potential of pesticides and fertilizers in the environmental horticulture industry: I. Greenhouse, nursery, and sod production. HortTechnolgy 6: 115-124.

Laurie,A. and E.W. Mc Elwee. 1934. A method for studying nutrient deficiencies in greenhouse crops. Proc. Amer. Soc. Hort. Sci. 32:617-619.

Lawton, K.A., G.L. McDaniel, and E.T. Graham. 1989. Nitrogen source and calcium supplement affect stem strength of poinsettia. HortScience 24: 463-465.

Lee, C.W., J.M. Cheri, and C.H. Pak. 1996. Micronutrient toxicity in seed geranium (Pelargonium $\times$ hortorum Bailey). J. Amer. Soc. Hort. Sci. 121:77-82.

Mankin, K.R. and R.P. Flynn. 1996. Nutrient uptake response of New Guinea impatiens to light, temperature and nutrient solution concentration. J. Amer. Soc. Hort. Sci. 121:826-830.

Markus, D.K. 1986. Spurway/Acid extraction procedures. HortScience 21: 217-222.

McAvoy, R.J. 1994. Nitrate nitrogen movement through the soil profile beneath a containerized greenhouse crop irrigated with two leaching factions and two wetting agent levels. J. Amer. Soc. Hort. Sci. 119:446-451.

McAvoy, R.J. and B.B. Bible. 1996. Silica sprays reduce the incidence of severity of bract necrosis in poinsettia. HortScience 32:1146-1149.

Meerow, A.W. 1994. Growth of two subtropical ornamentals using coir (coconut mesocary pith) as a peat substitute. HortScience 29:1484-1486

Mills, H.A. and J.B. Jones. 1996. Plant analysis handbook II. A practical sampling, preparation, analysis and interpretation guide. MicroMacro Publ. Co., Athens, Ga.

Milks, R.M., W.C. Fonteno, and R.A. Larson. 1989. Hydrology of horticultural substrates: I. Mathematical models for moisture characteristics of horticultural container media. J. Amer. Soc. Hort. Sci.114:48-52.

Nau, J. 1996. Ball perennial manual: Propagation and production. Ball Publ., Batavia, Ill.

Nell, T.A., J.E. Barrett, and R.T. Leonard. 1989. Fertilization termination influences postharvest performance of pot chrysanthemums. HortScience 24:996-998.

Nell, T.A., J.E. Barrett, and R.T. Leonard. 1997. Production factors affecting post production quality of flowering plants. HortScience 32:817-819.

Neumaier, E.F., T.M. Blessington, and J.A. Price. 1987. Effect of light and fertilizer rate and source in flowering, growth and quality of hibiscus. HortScience 22:902-904.

Newman, S.E., K.L. Panter, M.J. Roll, and R.O. Miller. 1997. Growth and nutrition of geraniums grown in media developed from waste tire components. HortScience 32:674-676.

Papadopoulos, A. (ed.). 1999. Proceedings of the international symposium on growing media and hydroponics. Vols. 1 and 2. Acta Hort. 481.

Parent, L.E. and M. Dafir. 1992. A theoretical concept of compositional nutrient composition. J. Amer. Soc. Hort. Sci.117:239-242.

Parent, L.E. and R.L. Granger. 1989. Derivation of DRIS norms from a highdensity apple orchard established in the Quebec Appalachian mountains. J. Amer. Soc. Hort. Sci.114:915-919.

Picchioni, G.A., M. Valenzuela-Vaquez, and S. Armenta-Sanchez. 2001. Calcium-activated root growth and mineral nutrient accumulation of Lupinus havardii: Ecophysiological and horticultural significance. J. Amer. Soc. Hort. Sci. 126:631-634.

Pridham, A.M.S. and R.G. Thompson. 1930. A study of the gladiolus with reference to preseason bloom. Proc. Amer. Soc. Hort Sci 27:305-307.

Reddy, K.S. and H.A. Mills. 1991. Interspecific responses of marigold to manganese as influenced by nitrogen source. HortScience 26:1281-1282.

Reed, D.W. (ed.). 1996. A grower's guide to water, media and nutrition for greenhouse crops. Ball Publ. Co., Batavia, Ill.

Reuter, D.J and J.B. Robinson. 1997. Plant analysis: An interpretation manual. 2nd ed. CSIRO Publ., Collingwood, VIC, Australia

Rogers, M.N. and B.D. Tija. 1990. Gerbera production. Timber Press, Inc., Portland, Ore.

Rose, M.A., J.W. White, and M.A. Rose. 1994. Maximizing nitrogen use efficiency in relation to growth and development of poinsettia. HortScience 29:272-276

Rosen, C. J., Errebhi, and W. Wang. 1996. Testing petiole sap for nitrate and potassium: A comparison of several analytical procedures. HortScience 31:1173-1176.

Roude, N., T.A. Nell, and J.E. Barrett. 1991. Longevity of potted chrysanthemums at various nitrogen and potassium concentrations and $\mathrm{NH}_{4}: \mathrm{NO}_{3}$ ratios. HortScience 26:163-165.

Rupp, L.A. and L.M. Dudley. 1989. Iron availability may affect rose nutrition. HortScience 24:258-260.

Salac, S.S. and J.B. Fitzgerald. 1983. Influence of propagation method of fertilizer rate on growth and development of Liatris pycnostachya. HortScience 18:198.

Sanderson, K.C., W.C. Martin, Jr., L. Shu, C. E. Evans, and R.M. Patterson. 1985. Fertilizer and irrigation effects on medium leachate and African violet growth. HortScience 20:1062-1064.

Schrock, P.A.T. and K.L. Goldsberry. 1982. Growth responses of seed geranium and petunia to nitrogen source and growing media. J. Amer. Soc. Hort. Sci. 107:348-352.

Scoggins, H.L., D.A. Bailey, and P.V. Nelson. 2001. Development of the press extraction method for plug substrate analysis: Quantitative relationships between solution extraction techniques. HortScience 36:918-921.

Seeley, J. 1979. Advancements in commercial floriculture during the past 75 years. HortScience 14:364-368.

Smith, M.A., G.C. Elliott, and M.P. Bridgen. 1998. Calcium and nitrogen fertilization of Alstromeria for cut flower production. HortScience 33:55-59.

Starkey, K.R. and A.R. Pedersen. 1997. Increased levels of calcium in the nutrient solution improves the postharvest life of potted roses. J. Amer. Soc. Hort. Sci. 122:863-868.

Tayama, H.K. and S.A. Carver. 1992. Comparison of resin-coated and soluble fertilizer formulations in the production of zonal geranium, potted chrysanthemum and poinsettia. HortTechnology. 2:476-479.

Todd, N.M. and D.W. Reed. 1998. Characterizing salinity limits of new guinea impatiens in recirculating subirrigation. J. Amer. Soc. Hort. Sci. 123:156-160.

Uva, W.F., T.C. Weiler, and R.A. Milligan. 2001. Economic analysis of adopting 
zero runoff subirrigation systems in greenhouse operations in the northeast and north central United States. HortScience 36:167-173.

van Iersel, M.W., R.B. Beverly, P.A. Thomas, J.G. Latimer, and H.A. Mills. 1998. Nutrition affects pre and post transplant growth of impatiens and petunia plugs. HortScience 33:1014-1018.

Vetanovetz, R.C. and J.C. Peterson. 1990. The fate of urea in a sphagnum peat medium as affected by lime source and rate. J. Amer. Soc. Hort. Sci.115: 386-389.

Wang, Y.T. and J.W. Sauls. 1988. Influence of light, medium and fertilization on growth and acclimatization of ponytail palm. HortScience 23:720-721.

Wang, Y. T. and T.M. Blessington. 1990. Growth and interior performance of poinsettia in media containing composted cotton burrs. HortScience 25: 407-408.

Warncke, D.D. 1986. Analyzing greenhouse growth media by the saturation extraction method. HortScience 21:223-225

Westerman, R. L. (ed.). 1990. Soil testing and plant analysis. 3rd ed. Soil Sci. Soc. Amer., Madison, Wis.

Whipker, B.E. and P.A. Hammer. 1997. Nutrient uptake in poinsettia during different styles of physiological development. J. Amer. Soc. Hort. Sci. 122: $565-573$.

White, J.W. and J.A. Biernbaum. 1984. Effects of root-zone heating on elemental composition of calceolaria. J. Amer. Soc. Hort. Sci. 109:350-355.

Widmer, R.E., M. Prasad, and R.R. Marshall. 1986. Peat and bark media nutrient levels in relation to geranium growth and tissue analysis. J. Amer. Soc. Hort. Sci. 111:4-7.

Williams, K.A. and P.V. Nelson. 1992a. Growth of chrysanthemum at low, relatively steady state nutrient levels in a commercial-style substrate. HortScience 27:877-880.

Williams, K.A. and P.V. Nelson. 1992b. Low, controlled nutrient availability provided by organic waste materials for chrysanthemum. J. Amer. Soc. Hort. Sci. 117:422-429.

Willits, D.H., P.V. Nelson, M.M. Peet, M.A. Depa, and J.S. Kuehny. 1992.
Modeling nutrient uptake in chrysanthemum as a function of growth rate J. Amer. Soc. Hort. Sci. 117:769-774.

Wilson, S.B., P.J. Stofella, and D.A. Graetz. 2001. Evaluation of compost as an amendment to commercial mixes used for container-grown golden shrimp plant production. HortTechnology 11:31-35.

Windsor, G. and P. Adams. 1987. Diagnosis of mineral disorders in plants. vol. 3. Glasshouse crops. Chem. Publ. Co., New York.

Woltz, S.S. and B.K. Harbaugh. 1986. Calcium deficiency as the basic cause of marginal tract necrosis of 'Gutbier V-14 Glory poinsettia'. HortScience 21:1403-1404.

Woodson, W.R. and J.W. Boodley. 1982a. Effects of nitrogen form and potassium concentration on growth, flowering and nitrogen utilization of greenhouse roses. J. Amer. Soc. Hort. Sci. 107:275-278.

Woodson, W.R. and J.W. Boodley. 1982b. Influence of potassium on the growth, flowering and chemical composition of greenhouse roses grown in recirculating nutrient solutions. HortScience 17:46-47.

Woodson, W.R., F.B. Negm, and J.W. Boodley. 1984. Relationship between nitrate reductase activity, nitrogen accumulation and nitrogen partitioning in chrysanthemum. J. Amer. Soc. Hort. Sci. 109:491-494.

Wright, R.D. 1986. The pour-through nutrient extraction procedure. HortScience 21:227-229.

Yeager, T.H., and J.E. Barrett. 1984. Phosphorus leaching from 32P-superphosphate-amended soilless container media. HortScience 19:216-217.

Yeager, T.H., R.D. Wright, and S.J. Donohue. 1983. Comparison of pour-through and saturated pine bark extract N, P, K and pH levels. J. Amer. Soc. Hort. Sci.108:112-114.

Yelanich, M.V. and J.A. Biernbaum. 1993. Root medium nutrient concentration and growth of poinsettia at three fertilizer concentrations and four leaching fractions. J. Amer. Soc. Hort. Sci. 118:771-776.

Young, J.R., E.J. Holcomb, and C.W. Heuser. 2002. Greenhouse growth of marigolds in three leached sources of spent mushroom compost over a 3year period. HortTechnology 12:701-705. 